\title{
Immigration Policy at the Subnational Level In North America: Quebec and Georgia In Comparative Perspective
}

\author{
RICHARD VENGROFF*
}

\begin{abstract}
One of the fundamental goals of immigration policy is the "integration" of new immigrants, which reaches its fullest success with naturalization. Most integration efforts take place at the subnational level. I use case studies of Georgia and Quebec to identify indicators and patterns that can be applied to the comparative study of immigration policy in Canadian provinces, U.S. American states and meso-level governmental units around the world. I believe my analysis captures some of the broad range of variation in immigration policy between Canadian and U.S. jurisdictions and helps us to assess the comparative success in terms of naturalization.
\end{abstract}

Key words: immigration, integration, Canada, U.S., naturalization, MIPEX.

\section{RESUMEN}

Una de las metas fundamentales de la política de inmigración es la "integración" de los nuevos inmigrantes, que alcanza su éxito total con la naturalización. La mayoría de los esfuerzos de integración ocurren en el nivel subnacional. Utilizo estudios de caso de Georgia y Quebec para identificar indicadores y patrones que pueden aplicarse al estudio comparado de la política de inmigración en las provincias canadienses, los estados de la unión americana y las unidades gubernamentales de nivel medio en todo el mundo. Mi análisis pretende mostrar el amplio rango de variación en las políticas migratorias entre las jurisdicciones de Canadá y Estados Unidos, y puede ayudarnos a evaluar el éxito comparativo en términos de naturalización.

Palabras clave: inmigración, integración, Canadá, Estados Unidos, naturalización, MIPEX.

* Professor of political science at Kennesaw State University and Fulbright Visiting Research Chair in North American Integration at Carleton University, Ottawa, vengroff.richard6@gmail.com 


\section{INTRODUCTION}

Increasingly, immigration issues have risen to the fore in public consciousness and among decision-makers not just at the national level but at the subnational level as well. The expansion of the role of Canadian provinces in immigration was spearheaded by Quebec, but now involves all the others, albeit in a less significant way. Quebec's leadership in immigration has been primarily motivated by nationalist, cultural, linguistic, and economic considerations and tends to be pro-immigration and integration of immigrants into Quebec society. This is not the case with U.S. American states, which, in terms of legal immigration, participate only in refugee resettlement, but not in systematic ways in other core areas of immigration policy like integration, recruitment, and selection. However, in the last few years, states have begun to play a more profound role in the area of "undocumented" ("illegal") immigration. This involves primarily the sphere of enforcement, culminating in restrictive immigration laws in Arizona, Georgia, Alabama, South Carolina, Utah, and Indiana, and similar proposals in other state legislatures.

To gain a better understanding of the role and processes of integration and naturalization, it is thus necessary to explore the role of subnational units in immigration. However, there has been little real comparative data on immigration policy at the state and provincial levels where much of the action now appears to be taking place. It is clear that these subnational policies are not uniform, especially within federal countries like the U.S. and Canada. In Canada, the role of Quebec is quite different from that of Ontario, for example, while in the U.S., Georgia's policies are quite different from those of New York. One of the aims of this article is to help identify indicators and patterns that can be applied to the comparative study of immigration policy in Canadian provinces, U.S. American states and meso-level governmental units around the world more generally.

Perhaps the best way to understand a policy like immigration is to examine it from a comparative perspective. In this article, I employ an inductive approach, initially using case studies of Quebec and Georgia to capture some of the broad range of variation in immigration policy between Canadian and U.S. jurisdictions. Therefore, throughout, I will compare immigration policies in Quebec with those of other Canadian provinces and U.S. American states, particularly Georgia.

In recent years, interest has grown in the comparative study of immigration. One major effort to lay the groundwork for systematic comparative analysis, the Migration Integration Policy Index (MIPEX), was developed by the British Council and the Migration Policy Group. It is designed to measure and compare immigration policies in European Union (EU) member states, plus Norway, Switzerland, the U.S. 
and Canada (MIPEX, 2010) at the national level. ${ }^{1}$ That research identifies seven major policy areas: labor market mobility, family reunification, education, political participation, long-term residence, access to nationality, and anti-discrimination. The shortcoming of the index is that it fails to take into account the fact that many of those functions, especially in terms of implementation, are under the purview of or at least shared with intermediary and local governments and vary significantly between these units in the same country. Increasingly immigration issues have come to the fore in the public consciousness and among decision-makers at the subnational level throughout Canada, the U.S., Europe, Africa, Australia, and New Zealand.

By definition, immigration policy involves national governments in the issue of citizenship and residency, whether permanent or for limited time periods, and includes economic, family, social, human rights, refugee, and asylum-seeker concerns. ${ }^{2}$ Intermediate administrations like provincial governments and states are involved because of economic and employment needs, residency -all immigrants live in local jurisdictions-, education, health, language, social services, and cultural integration. In Canada, provinces, particularly Quebec, can also play a key role on the selection side. In the U.S., states have very little say in the selection of legal immigrants. In terms of "illegal" immigrants, some states are increasingly involved in policing and the potential deportation of the undocumented. In Canada, that remains an entirely federal function.

Currently, little comparative data exists on immigration policy at the provincial and state levels in either Canada and the U.S. or the EU. One of the key aims of this research is to identify indicators that can be applied comparatively at the subnational, particularly the intermediary, meso (state and province) level. In this article, I employ a comparative inductive approach (Lijphart, 1971) examining two important yet very similar case studies, Georgia and Quebec. However, in terms of the key policy variable, immigration policy, they may be regarded as polar opposites. Using deep case analysis, I will attempt to derive common core comparative indicators. This research will provide a clearer picture of the diversity of immigration policies being applied throughout the United States and Canada and establish the basis for comparison with provincial-, regional-, and state-level units in EU countries and elsewhere. It will provide the basis for a preliminary assessment of the comparative success in terms of naturalization of immigrants in Georgia and Quebec.

Several key assumptions underlie this study of immigration policy. My base assumption is that among the fundamental goals of immigration policy is the "integration"

\footnotetext{
${ }^{1}$ Australia and Japan have recently (2012) been added to the MIPEX.

${ }^{2}$ Switzerland, with permanent residency decided at the canton level and citizenship at the municipal level, is the most notable exception.
} 
of new immigrants, which reaches its fullest success with naturalization (citizenship). Although some scholars would question the use of naturalization as the endpoint of integration, it does provide a clearly comparative assessment tool for examining immigration policy. It is one of the key variables in the MIPEX Index: "access to nationality." This measure is highly correlated with the overall MIPEX ranking of a country. For example, on the overall rating based on 148 different indicators (among 31 countries in the MIPEX III), Canada ranks third overall and third on the "access to nationality" measure. The comparable rankings for the U.S. are ninth and ninth.

As suggested by the MIPEX approach, the success of immigration policy depends on the nature and quality of the legal and political framework and government sponsored integration efforts (MIPEX, 2012). Strong government intervention efforts at integration are employed in the Canadian model, In the U.S., the so-called "laissez-faire" approach is practiced where little if any integration services are publicly funded or offered.

Based on these empirically supported assumptions, the key operational hypothesis of this article is that the policy choices available to and made by provinces and states are reflected in multiple ways in the rate of success of the immigrant population (integration and citizenship) and simultaneously in the attitudes and interactions between their respective countries.

\section{Motivation for Subnational InVolvement in Immigration}

A number of key factors have contributed to a trend toward greater involvement by meso-units in immigration. These include increasing globalization, new international -including continental- trade agreements, the on-going impact of federalism, nationalism, and the process of decentralization.

Global competitiveness now dictates that in addition to sovereign countries, states, provinces, and cities must work to attract and retain the most creative talent, regardless of national origin and cultural and lifestyle preferences (Florida, 2005). Immigration policy designed to attract and retain talent and investment has become a critical component of policies calculated to address global competitiveness. Canada, China, India, the UK, and other EU members all have serious merit-based programs to attract the "best and the brightest" (Gafner and Yale-Loehr, 2010). Subnational units all over the industrial world are working in various ways to ensure their positions as "globally" attractive and, hence, competitive in terms of human resources. For example, in the Canadian case, how provinces set their priorities for economic development directly impacts the countries from which they seek to attract or discourage 
immigrants. According to the Canadian minister of immigration, "The prime goal is a fast and flexible immigration system whose primary focus is meeting Canada's economic and labour needs" (cIc News, 2012).

In the U.S, the Comprehensive Immigration Reform Act proposed as a bipartisan initiative in 2007 by then-President George Bush would have changed "the balance of legal immigration away from family reunification and toward admitting English speaking immigrants with specialized skills" (Citrin and Sides, 2008: 54). For the moment, the U.S. remains far behind its competitors in launching comparable programs. However, since the conclusion of the recent presidential election and the growing significance of Hispanics as voters, immigration reform has been given a high priority with the second Obama administration. The need to increase the number of visas for highly-skilled workers (H1B, 1-5) is the most politically accepted aspect of reform in the U.S. immigration system. Once again, however, it seems that comprehensive immigration reform in the U.S. faces very significant political hurdles.

Constitutional issues also come into play. While immigration (entry, permanent residence, and citizenship) are clearly in the purview of the federal government in Canada, post-arrival functions such as language training, healthcare, settlement, social services, labor, and employment remain provincial prerogatives (McIlroy, 1997: 434; Nossal, 1997; Dupras, 1993). All of the provinces and territories are committed "to working together . . . in three priority areas: immigration levels planning, economic immigration, and settlement and integration of newcomers." (CIC News, 2012). By way of contrast in North America, in Mexico such activities are constitutionally prohibited, but increasingly tolerated.

The U.S. Constitution explicitly mentions immigration, ${ }^{3}$ and the U.S. Supreme Court has ruled that Article 1, Section 8 assigns the naturalization of citizens (and hence immigration) to the federal government (White, 2012). The individual states have little or no direct say in the recruitment or acceptance of "legal" immigrants. The only area in which they have significant input and involvement is in refugee resettlement, an area in which they are at least consulted by Washington. Refugees and asylum seekers, however, represent a very small portion of legal immigrants admitted to the U.S. The positive potential role of the states in the selection of immigrants based on economic development and labor needs has been largely under-utilized and government heavily critiqued by the business community as hindering economic development.

\footnotetext{
${ }^{3}$ The word "naturalization" was the commonly used word for immigration when the Constitution was written.
} 


\section{The Cases for Analysis: Quebec and Georgia}

In a number of important ways Georgia and Quebec share some very important characteristics. Both include relatively large geographic areas. Although Quebec has a much greater surface area, the size of the populated zones is fairly similar. Georgia has 9.7 million residents (2010), while Quebec has 7.9 million (2011). Both are very active in the technology sector, in industrial production and agriculture. The level of trade between the two is considerable, with Canada as Georgia's largest trade partner and Quebec involved in a significant portion of that. Each is dominated by a large metropolitan region, Atlanta and Montreal respectively, where roughly half the people and the vast majority of new legal immigrants choose to reside (81.6 percent and 86.9 percent respectively). However, on the issue of legal immigration, Georgia and Quebec are on different trajectories in terms of both policy and public opinion. They therefore meet the basic conditions for a good comparison (Lijphart, 1971).

Legal immigration to Georgia averages about 28000 a year (27 015 in 2011); the largest source is Asia, accounting for just over 40 percent (led by India, China, South Korea, and Vietnam, in that order). More than four out of five new fully documented immigrants settle in the greater Atlanta metropolitan area. The state's foreign-born inhabitants number just under a million, or about 10 percent of the total population. However, of those, approximately 460000 are undocumented (Hoefer, Rytina, and Baker, 2012). Uncontrolled, "undocumented" immigration has become the dominant source of new international residents. Overall, the single largest immigrant group in Georgia is composed of undocumented Mexican workers and their families.

In the last few years, several U.S. states have begun to play a greater role in immigration vis-à-vis the undocumented, based on the delegation of immigration authority as stipulated in Section $287(\mathrm{~g})$ of the Immigration and Nationality Act. Sixtyeight law enforcement agencies in twenty-four states (Beeks and Frye, 2012) have become involved in implementation, in many but not all cases, in collaboration with the federal government. An indicator of this involvement is the fact that "in 2010, state legislatures in 47 states enacted 346 immigration-related laws and resolutions" (American Immigration Council, n.d.). Virtually all these laws involve restrictions and in some cases proactive state and local efforts to deny access to state services and to arrest and deport undocumented immigrants. In the state of Georgia, four counties (Cobb, Gwinett, Hall, and Whitford) continued to participate until the program was terminated in June 2013. Since 2006, over 16287 people in Georgia have been deported or voluntarily departed under this program. The Secure Communities Program, a national fingerprint data base is now in use in all prisons in the U.S., in collaboration with local law enforcement officials and will replace 287(g). 
In this type of legislation, historically, California led the way with anti-undocumented immigrant Proposition 187, which passed in referendum in 1994 but was declared unconstitutional three years later. That law would have cut all benefits to the undocumented (Huffington Post, 2012). More recently, other state governments have responded to the lack of comprehensive immigration reform and a perceived ineffective enforcement of existing federal laws. The now infamous sB1070 passed in Arizona has become a model, although a legally contested one, for laws passed in a number of other states, culminating in recent restrictive immigration legislation in Georgia, Indiana, Alabama, South Carolina, and Utah and similar proposals in numerous other state legislatures (Beeks and Frye, 2012; White, 2012). On the other side of the coin, in October 2013, California became the eleventh state to allow "illegal" immigrants to obtain drivers licenses.

\begin{tabular}{|c|c|}
\hline & $\begin{array}{c}\text { Table } 1 \\
\text { KEY GEORGIA ANTI-IMMIGRATION LAWS }\end{array}$ \\
\hline Law/Agreement & Description \\
\hline $\begin{array}{l}\text { Georgia Security } \\
\text { and Immigration } \\
\text { Compliance Act }\end{array}$ & $\begin{array}{l}\text { 6-percent state withholding tax for } 1099 \text { employees who cannot } \\
\text { provide a taxpayer ID number; required citizenship verification of } \\
\text { state employees and employers with state contracts and subcon- } \\
\text { tracts; citizenship verification to establish eligibility for individuals } \\
\text { over } 18 \text { years of age seeking state services }\end{array}$ \\
\hline $\begin{array}{l}\text { Memorandum of } \\
\text { Understanding with } \\
\text { ICE for } 287(\mathrm{~g})\end{array}$ & $\begin{array}{l}\text { Permits local law enforcement agencies to perform immigration } \\
\text { enforcement functions in collaboration with ICE; } 4 \text { Georgia county } \\
\text { sheriffs, plus the Georgia Department of Public Safety participate; } \\
3 \text { private jails in Georgia hold detainees }\end{array}$ \\
\hline SB20 & $\begin{array}{l}\text { Prohibits "sanctuary" policies by county and municipal govern- } \\
\text { ments and agencies ("catch and release"); authorities must deter- } \\
\text { mine lawful presence in the U.S. of those stopped for violations }\end{array}$ \\
\hline $\begin{array}{l}\text { Immigration Reform } \\
\text { and Enforcement } \\
\text { Act (HB87) }\end{array}$ & $\begin{array}{l}\text { Several provisions similar to Arizona law (SB1070); several pro- } \\
\text { visions disallowed by courts (recruitment, transport, "show me } \\
\text { your papers"); upheld checks on those stopped or arrested for } \\
\text { other issues. Establishes Immigration Enforcement Review Board } \\
\text { (IERB) to investigate complaints made by citizens (registered voters } \\
\text { only) about non-enforcement by state and local officials }\end{array}$ \\
\hline
\end{tabular}




\section{QUEBEC}

The role of provinces in immigration in Canada, spearheaded by Quebec, has expanded dramatically since 1990. We should recall that Canadian provinces, and especially Quebec, play a very active role in both the recruitment and selection processes for immigrants. In Quebec, roughly one in nine residents (about the same percentage as for Georgia) was born outside the country (compared to about 20 percent for Canada and 28 percent for neighboring English-speaking, Ontario). This may reflect the fact that the top immigrant-sending countries to Canada over the last 40 years have been English-speaking (the UK, the U.S., India, and Hong Kong) (Gogia and Slade, 2011). Quebec selects its immigrants largely from the economic category (69.8 percent), with about one in five (19.4 percent) from the family reunification category, and one in 10 (9.7 percent) who have refugee status. Through its Ministry of Immigration and Cultural Communities, and under the Canada-Quebec Accord, Quebec is charged with putting together and updating a strategic five-year immigration plan for the province, setting priorities about characteristics and types of immigrants desired and coordinating the effort with Ottawa in what amounts to an "asymmetrical" federalist model. The provincial role in targeting immigrants as part of the broader economic growth, and the preservation of cultural identity contributes to making Quebec a place where both government and citizens generally favor immigration.

Table 2

TIMELINE OF QUEBEC'S INVOLVEMENT IN IMMIGRATION

\section{Year Accord or Action}

1968 Quebec established its own immigration department

1971 The first Canada-Quebec immigration agreement was signed (Lang/Cloutier), allowing Quebec to have representatives in Canadian embassies and to do counseling abroad

1975 The Andras/Bienvenue agreement gave Quebec a part in the selection process, allowing Quebec to do interviews and to make recommendations to visa officers

1978 The Cullen/Couture agreement gave Quebec a say in the selection of immigrants abroad, allowing Quebec to define its own selection criteria

1991 Gagnon-Tremblay, Rémillard /McDougall Accord builds on this mutual commitment; it was the first agreement to give Quebec selection powers in Canada

Source: Government of Canada, Immigration and Citizenship (2011a). 


\section{Table 3}

GAGNON-TREMBLAY/MCDOUGALL CANADA-QUEBEC ACCORD 1991 KEY PROVISIONS

1. This accord relates to the selection of persons who wish to reside permanently or temporarily in Quebec, their admission into Canada, their integration into Quebec society, and the determination of levels of immigration to Quebec.

2. One objective is the preservation of Quebec's demographic importance within Canada and the integration of immigrants to that province in a manner that respects Quebec's distinct identity.

3. Canada shall determine national standards and objectives relating to immigration and shall be responsible for the admission of all immigrants and the admission and control of aliens. Canada shall discharge these responsibilities in particular by defining the general classes of immigrants and classes of persons who are inadmissible into Canada, by setting the levels of immigration and the conditions for the granting of citizenship, and by ensuring the fulfillment of Canada's international obligations.

4. Quebec has the rights and responsibilities set out in this accord with respect to the number of immigrants destined to Quebec and the selection, reception, and integration of those immigrants.

Source: Government of Canada, Immigration and Citizenship (2011b).

The importance of immigration at the provincial level is underlined by the very significant investments in it. All 10 Canadian provinces and the three territories have ministries/services/departments, and, in one case, PEI, a crown corporation, to deal with immigration and immigration-related issues. Section 95 of the Constitution Act is cited as legitimizing the sharing of authority between the provinces and the federal government regarding immigration.

In Canada, Quebec led the way, establishing under the Union Nationale government of Premier Daniel Johnson, Sr., a Department of Immigration in 1968. This was an area of high priority for Quebec, particularly for "sovereignists," as a symbol of nationhood. The philosophical/legal justification was provided by the Gérin-Lajoie Doctrine, which argues that treaties signed by the Canadian government that involve provincial functions can only be implemented with the agreement of the province. Furthermore, the argument goes that provinces have the right to engage in international agreements of their own in areas of provincial responsibility. Even though the federal government in Canada never recognized the Gérin-Lajoie doctrine, much of it has been implemented de facto. As can be seen in Table 2, a series of agreements between Quebec and the Canadian government expanded the provincial role and legitimacy in immigration. These gradually evolved from the placement of Quebec representatives in Canadian embassies into the prominent leadership role Quebec has played in this process since 1991. 
The Cullen-Couture Agreement of 1978, negotiated under the government of René Levesque, codified the serious collaborative role of Quebec and Ottawa in the implementation of immigration policy. In 1990, this agreement was expanded and a year later replaced with a new intergovernmental accord (the Gagnon-Tremblay, Rémillard/McDougall Accord). This agreement includes the transfer of federal funds to Quebec for the implementation of immigration policy, especially integration programs for immigrants. The agreement's key provisions show Quebec's core values and goals in terms of the social, cultural, and economic realms. This agreement remains in effect right up to the present and provides Quebec with a leading but collaborative role in immigration, a role only partially shared by other provinces. For example, while the other provinces' and territories' representatives met with the federal government to work out a new agreement on strategic objectives and new approaches (particularly the new "expression of interest," or EOI, initiative), Quebec's minister of immigration chose not to attend. The backgrounder on the meeting clearly stated that the agreement did not in any way affect past agreements on immigration under the Canada-Quebec accord.

The current Ministry of Immigration and Cultural Communities in Quebec employs nearly 1600 staff and has four overseas immigration offices (Paris, Hong Kong, Mexico City, and Brussels) and seven regional offices throughout Quebec. For most of the provinces, active involvement in immigration began in 2001 with the "Provincial Nominee Program," launched in collaboration with the federal government. That program allows provinces to nominate a relatively small number of individuals for immigration to Canada based on the economic and skilled-labor needs they determine. All Canadian provinces are now employing this mechanism, with revisions based on an agreement reached in November 2012. In addition to Quebec, two other provinces, Ontario and Alberta, have elevated immigration to ministerial status. Most others have an office embedded in a ministry with broader responsibilities (often intergovernmental relations or commerce).

\section{The Importance of Public Opinion about Legal Immigration}

Canada is an outlier among advanced industrial nations in terms of the overall degree of support for "existing levels" of immigration. In the U.S., a country whose image is inextricably linked with immigration ("We are a nation of immigrants."), public opinion lies somewhere between that in Canada and Western European nations on this issue. As noted, "Europeans display negative attitudes towards immigrants in general and to immigration in particular" (Davidov and Meuleman, 2012). 
Right wing anti-immigrant political parties seem to be in the ascendancy in much of Europe (for example, the Netherlands, Denmark, etc.)

According to Bloemraad (2012) "About two-thirds of Canadians feel that immigration is a key positive feature of their country." This support is quite consistent across Canada's, provinces, including Quebec. The picture is far less positive in U.S. American states where immigration, on the input side, remains almost entirely in the hands of the federal government. It has recently become a salient issue, since 9/11 and the rise in concern about the number of undocumented immigrants.

Measuring support for or opposition to immigration using survey research methods can be quite daunting. As Jedwab (2008) demonstrated, changing the introduction to some commonly used immigration-related survey items can change the responses quite significantly. In several surveys of U.S. citizens only, 18 percent agreed that immigration has a positive effect on the country, while in a recent PEW survey, 49 percent agreed with the statement "immigrants today strengthen our country because of their hard work and talents" (Pew Research, Center for the People and the Press, 2013). Even so, for comparative purposes two survey items, the question of increasing, keeping the same, or decreasing immigration levels (without telling the interviewee the actual numbers,) and the question of whether immigration is good or bad for the country, still produce useful comparative data on perceptions.

Overall, public opinion in Canada remains quite favorable to immigration, especially when compared to the U.S. and other Western democracies. Support by Canadians remains high, even in the face of economic challenges (Hiebert, 2006; Simon and Sikich, 2007). What accounts for this and the differences between Canada and other advanced industrial nations on this issue? This support is rooted in the country's perceived economic, social, demographic, and historic cultural dimensions (particularly "multiculturalism") (Reitz, 2011). Fortin and Loewen (2004) disaggregated responses (increase level, remain the same, and decrease level of immigration) and found different dynamics associated with support for increasing or maintaining current levels of immigration and for establishing restrictions on immigration. These differences are based on economic and cultural affinity and symbolic politics hypotheses. Individual prejudice came into play in explaining the "decrease the level of immigration" responses but showed little impact in the others.

These findings need to be nuanced by changes occurring over time. As indicated in Table 4, Canadians are now evenly split on whether immigration has a positive or a negative effect on the country (39 percent to 39 percent). This is still far more positive, however, than similar findings in Europe, where those saying the impact is negative outnumber those saying it is positive by nearly two to one. Furthermore, Québécois are far more positive than Canadians as a whole (44 percent positive vs. 
32 percent negative). Surprisingly in Ontario, the province with the largest number of immigrants, trends are moving in the negative direction.

\begin{tabular}{|c|c|c|c|c|c|}
\hline ATTITUDES TOW & $\begin{array}{r}\text { Table } \\
\text { ARD IMMIGRATIC }\end{array}$ & $\begin{array}{l}4 \\
N \text { IN THE }\end{array}$ & U.S. AND & CANADA & \\
\hline Statement in Survey & $\begin{array}{l}\text { United States } \\
(\%)\end{array}$ & $\begin{array}{c}\text { Canada } \\
(\%)\end{array}$ & $\begin{array}{l}\text { Quebec } \\
\text { (\%) }\end{array}$ & $\begin{array}{l}\text { Georgia } \\
(\%)\end{array}$ & $\begin{array}{c}\text { Ontario } \\
\text { (\%) }\end{array}$ \\
\hline $\begin{array}{l}\text { Immigration in the country } \\
\text { should be decreased }\end{array}$ & 35 & 41 & 44 & 48 & 44 \\
\hline $\begin{array}{l}\text { Immigration in the country } \\
\text { should be maintained at } \\
\text { present levels }\end{array}$ & 42 & 37 & 36 & 32 & 36 \\
\hline $\begin{array}{l}\text { Immigration in the country } \\
\text { should be increased }\end{array}$ & 21 & 15 & 11 & 11 & 15 \\
\hline $\begin{array}{l}\text { Immigration has a positive } \\
\text { effect on the country* }\end{array}$ & 18 & 39 & 44 & & 35 \\
\hline $\begin{array}{l}\text { Immigration has a negative } \\
\text { effect on the country }\end{array}$ & 57 & 39 & 32 & & 42 \\
\hline $\begin{array}{l}\text { Not sure of the effect of } \\
\text { immigration on the country }\end{array}$ & 25 & 22 & 24 & & 22 \\
\hline $\begin{array}{l}\text { * Wording has a dramatic effec } \\
\text { Source: United States (Gallup, } \\
\text { Institute of Government, 2006 }\end{array}$ & $\begin{array}{l}\text { responses to th } \\
\text { 2); Canada (An }\end{array}$ & $\begin{array}{l}\text { type of } \\
\text { as Reid F }\end{array}$ & $\begin{array}{l}\text { destion. } \\
\text { blic Opini }\end{array}$ & Georg & arl Vinson \\
\hline
\end{tabular}

Some additional evidence seems to be consistent with the Canadian "exceptionalism" thesis. A recent study found, surprisingly, that higher levels of national pride are associated with support for immigration in both Quebec and English-speaking Canada, while the reverse is the case in the U.S. (Citrin and Wright, 2012). Looking at Francophone and Anglophone daily newspaper reactions to a new government guide defining citizenship for new and potential immigrants, Winter and Sauvageau (2012) found a convergence of opinion. This suggests consensus around "core values" that guide immigration efforts throughout Canada.

Linked to these core Canadian values is a sense of fairness, especially as it relates to the undocumented. According to a recent Angus Reid poll, "the views of Canadians on illegal immigration have hardened. . . Half of respondents (50 percent, +6 since September 2010) believe illegal immigrants in Canada take jobs away from Canadian workers"' (Angus Reid Global, 2012). In addition, only 23 per cent of respondents 
would allow illegal immigrants to stay in Canada and eventually apply for citizenship, while 50 percent think illegal immigrants should be required to leave their jobs and be deported" (Angus Reid Global, 2012). These findings regarding sanctions for "illegal" immigration surprisingly approach levels currently found in the U.S., where the undocumented are far more numerous and it is a more salient issue.

On the negative side, the "cultural affinity" arguments, often labeled "reasonable accommodation," came to the fore in Quebec and spread across Canada, as they have in many Western European countries. In 2007, the small Quebec municipality of Hérouxville publicly raised the issue in dealing with immigrants, specifically in relation to some perceptions of Muslim and Sikh practices. It immediately became salient and resulted in the creation of a provincial commission and widespread debate and discussion.

The Liberal government in the National Assembly in Quebec City passed Bill 94 in 2010 requiring Muslim women to show their faces in public in order to receive government services. Although this was quite controversial and regarded by many as anti-Muslim, it hit a responsive chord across Canada. In a national survey, the Angus Reid Global (2010) reported 80-percent approval of the bill by Canadians (and 95 percent of Quebecois). According to Quebec's immigration minister "to work in the Quebec public service or to receive the services of the Quebec state, your face has to be uncovered." The Canadian government followed suit in December 2011 with a similar administrative regulation put into effect by the federal minister of citizenship and immigration (National Post, 2011). Furthermore, the so-called Charter of Secularism being considered by Quebec's National Assembly would make it illegal for government officials to wear religious symbols while on the job.

Thus, even in one of the most welcoming of countries in the world, attitudes vary considerably depending on how an immigration issue is framed and the context and the nature of the immigration-related policies at the provincial level. In the print media, Winter and Sauvageau (2012) noted the sense that core culture and values need to be protected from the "other," Muslims in particular. The controversy has not entirely disappeared and was raised again in Quebec's 2012 provincial election campaign. The discussion once more brought to the fore the issue of the wearing and display of religious symbols by government workers. Pauline Marois, at the time leader of the opposition Parti Québecois (PQ) -now leader of a minority government-, contended that Quebec is a secular state. She proposed a new Secularism Charter. "Civil servants," she argued, "should not be allowed to wear" obvious religious signs such as turbans, "yarmulkes," and "hijabs" (Séguin and Clark, 2012). When a PQ candidate for the National Assembly, Djemila Benhabib, stated that the crucifix ought to be removed from the Quebec legislature, she was attacked by the mayor of Saguenay 
who said Quebecois should not be dictated to by someone from Algeria. Benhabib narrowly lost the election in Trois Rivière to a Liberal Party candidate. We do not know how much this controversy contributed to that outcome, but I would suspect it had at least a small impact. The debate became even more heated when the discussion turned to making sure that new immigrants were prepared to adopt and/or adapt to Francophone Quebec language and culture. In this, the Coalition for Quebec's Future (Coalition Avenir Quebec, or CAQ) concurred with the "Péquistes," or members of the Parti Québecois (PQ).

Among the major Quebec parties, there was considerable variation in the emphasis placed on immigrants. The PQ proposed creating a distinct Quebec citizenship that would apply to all current residents but limiting access to future immigrants to those who speak French and know about the history, culture, and values of Quebec. Furthermore, it proposed restricting access to English medium general and vocational colleges (CEGEPS, or the equivalent of junior colleges) for newcomers to the province and not allowing Francophone Quebecois to study in them either. They went on to argue in favor of requiring French fluency for all candidates for public office (Beaudin, 2012). On the economic side, companies with fewer than 50 employees, heretofore excluded from Bill 101, would now be subjected to French-language requirements in the workplace.

The CAQ, an upstart successor to Democratic Action (Action Democratique, or $\mathrm{AD})$, suggests cutting back on the number of immigrants admitted and strengthening the program of "Francization" in order to protect the French language. The Liberal Party, which actively sought the support of "Allophones" (an immigrant whose mother tongue is neither English nor French), generally avoided the immigration debate, except for offering greater support for French-language programs for new immigrants and the dissemination of a "Quebec values" statement to all actual and potential immigrants.

The September 4 elections put the $\mathrm{PQ}$ in office, but as a minority government with only 54 of 125 seats and the support of only 32 percent of the electorate. As noted above, its program emphasized some not insignificant immigration-related issues (establishing a Quebec citizenship, additional language tests, language restrictions on running for office, and limits on access to English-language CEGAPs). However, as the leader of a minority government, Pauline Marois had to put some of these plans on hold or at least modify them before they could be presented to the National Assembly. The CAQ and Liberal Party leaderships have already labeled several of Marois's immigration proposals as non-starters.

Some accommodations may be possible for the PQ government if an informal accord can be reached with the third-place party, CAQ (19 seats), which also favors 
some modifications in immigration policy, especially regarding language, integration, and numbers. Marois, as a strong advocate for Quebec independence, has talked about confronting Ottawa and demanding more control for Quebec over a variety of policies, including immigration. The emphasis is on strengthening the French-language component for admission and training of immigrants. In an October 2, 2012 press release, the new minister is quoted as saying, "This preoccupation is consistent with my charge in immigration as well as language. The vitality and quality of the French language includes the "Francization" of new arrivals and is clearly a priority for me." The release of linguistic data from the 2011 census showing mixed results for French usage, particularly in Montreal, has sparked new demands by the PQ to strengthen the historic Bill 101.

Unlike the U.S., Canada employs a point system for new immigrants that emphasizes the economic and labor needs of the country and the provinces. About 60 percent of all new immigrants are classified as "economic immigrants." They "apply for permanent residence papers and are selected by Canadian governments based on their education, language skills, occupational training, work experience, and age. An additional, smaller group is chosen based on ability to invest in business and job creation" (Bloemraad, 2012). Only about a quarter are admitted based on family ties and 11 percent as refugees. Contrast this to the U.S., where selection and admission policies are almost the exact reverse, dominated by family relations rather than economic needs.

As per the accord between the province of Quebec and Ottawa, responsibilities are shared with the federal government. The Quebec Ministry of Immigration and Cultural Affairs maintains four overseas immigration offices for recruitment and screening of potential immigrants and seven regional offices in Quebec to assist new immigrants in adapting and for local governments to coordinate their employment needs. Quebec selects immigrants for the economic category, for some in the refugee category (overseas), and for certain humanitarian purposes (for example, Haiti after the earthquake). The federal government does the selection for family reunification and asylum seekers. About three-quarters of all immigrants to Quebec are selected by the province, issued Quebec certificates of acceptance, and then accorded permanent resident status by the Canadian government. Figures for the first six months of 2012 for Quebec indicate that, consistent with past practice, 74.8 percent of immigrants to the province were selected by Quebec. They are subject to screening and final approval by the federal government based on health, national security, and crimerelated issues. Nonetheless, the overwhelming majority of those selected by Quebec are admitted. The numbers for this year continue to surpass expectations, with over 51000 admitted. The demand remains high and does not appear to have been 
affected by the internal charter of secularism debates (DeCourcy, cited in The Canadian Press, 2013).

After a series of public hearings conducted by its Ministry of Immigration, the Quebec government established goals for the 2012-2015 plan that include economic qualifications (65 percent), relative youth (65-75 percent under the age of 35 ), representation of diverse world regions, and the ability to speak or at least have some experience with and understanding of French (at least 50 percent). About 63 percent of new immigrants are French-speaking at some level, and all new immigrants are expected to master French after arriving. As noted above, the province issues a certificate of acceptance (selection) to those who meet their criteria and this is communicated to the federal immigration service in Ottawa. The ministry also contracts with nonprofits to help immigrants integrate into Quebec society.

Given the priority placed on language and prospects for integration into Quebec society, those admitted tend to come from Francophone countries, particularly France and former French colonies. The countries of the Magreb, especially Morocco, Algeria, and Tunisia, have been high on the list, along with Haiti, Lebanon, and Cameroun. Outside the Francophone world, China, Columbia, Iran, and Egypt contributed important numbers of immigrants in recent years.

In the revised point system, greater weight will be assigned to language competency, relative youth, Canadian work experience, and "the introduction of a mandatory assessment of educational credentials" (Quebec Immigration, 2012). This last requirement is designed to eliminate fraud and to assist with employment placement where professional credential equivalence is established. This seems to be very consistent with Quebec's broad policy goals. However, under the current PQ government, Quebec chose not to participate in a meeting of the federal and provincial immigration ministers. At this meeting the ministers unanimously approved major changes in policy designed to streamline and expedite immigrant selection. It will employ an "expression-of-interest" approach to the recruitment and acceptance of new immigrants under the Federal Skilled Workers Program. Based on a similar system launched in New Zealand and more recently in Australia, this approach will be implemented by the federal government and all provincial governments, except Quebec, in 2014. This policy moves in the direction of greater central control in Ottawa and less autonomy for the provinces. Quebec, however, will not be affected and will continue to operate under its existing agreement with Ottawa. (CIC News, 2012). Quebec has, however, adopted basically the same expression-of-interest model for its own use. 


\section{GeORGia ANd Immigration}

Interest in immigration issues reached a fever pitch in Georgia in 2010, following the arrest of a Kennesaw State University student, Jessica Colotl, on a minor traffic violation. This undocumented dean's list student, brought to Georgia by her parents at age 11, became a national cause célèbre for both the anti-immigrant and the pro-Dream Act groups. With a semester to go to graduate, she faced the prospects of deportation to Mexico. She was eventually granted a one year delay by ICE, but was forced to serve a brief jail sentence for driving without a license. ${ }^{4}$ This highly publicized incident and the virulent response by Tea Party ideologues led right-wing -and even some more moderate- Republican lawmakers to push for additional restrictions on state services to undocumented immigrants and passage of an Arizona-type immigration bill.

Although opinion on immigration in the U.S. is generally less positive than in Canada, perceptions of immigrants in different states and regions vary considerably (SurveyUSA, 2005). However, U.S. Americans tend to see little in the way of economic or social benefits from immigration, and rightly or wrongly, view it as a major drain on local resources.

To this mix, we need to add those without legal documentation authorizing their stay in the country. Issues surrounding undocumented immigrants have become extremely salient and highly politicized. The sheer magnitude of the "illegal immigrant" population in Georgia (estimated at 450 000, 325000 of whom held jobs in 2010) coupled with the linguistic, cultural, and class differences the undocumented immigrants represent, lead many Georgians and Georgia lawmakers to support an Arizona-type law to control it.

The Supreme Court recently struck down three of the Arizona law's four major provisions, and by extension, those of Georgia's anti-illegal immigration laws. "The five-justice majority was quite clear that the federal government has total authority over immigration law, and that states can assist only to the degree that the federal government allows that assistance. The court based its ruling in part on the federal government's clear, longstanding authority on matters of foreign policy. It is fundamental that foreign countries concerned about the status, safety, and security of their nationals in the United States must be able to confer and communicate on this subject with one national sovereign, not the 50 separate states," Justice Anthony Kennedy wrote for the majority ( $A B A$ NOW, 2012), and Justice Scalia, who would have upheld all four provisions in the law, wrote a strong dissent. The court also ruled that

\footnotetext{
${ }^{4}$ Remaining charges against Ms. Colotl were finally dismissed in January 2013.
} 
federal officials have exclusive discretion about deciding how -and even whetherto deport those who are in the country illegally (ABA Now, 2012).

The important provision left standing and that applies in Georgia requires police to check the immigration status of those stopped or arrested for other reasons. It is still being contested as discriminatory. Not challenged in the courts, however, is the creation in the bill in Georgia of the Immigration Enforcement Review Board (IERB). Composed of seven members appointed by the governor, the IERB allows citizens -registered voters only- to bring complaints against state agencies and local governments for non-enforcement of E-Verify for employees and contractors, "sanctuary cities" using the so-called "catch and release" policy, and provision of public benefits for the undocumented. The board composition (seven white men with limited knowledge and / or no immigration-related experience) and functions are being questioned by immigrant advocacy and civil liberties groups. Several cases have already been brought to the board by anti-immigrant activists. Interestingly, a recent audit discovered that the state's Department of Agriculture had failed to implement the E-Verify provision of state law until the end of 2012.

Georgia, like all U.S. states, has almost no legal control over the level of immigration and the selection of immigrants to the U.S. or the state. U.S. immigration policy places a high premium on family sponsorship and family reunification. Of the just over one million (1 062 040) legal immigrants to the U.S. in 2011, 65 percent were either family-sponsored or immediate family. Employment-based preferences, linked to economic development (EB1-5), account for only 13 percent, and refugees and asylum seekers 11 and 5 percent, respectively. The only immigration program that allows state governments to decide how many newcomers will come to the state each year is refugee settlement. However, this state-based agreement only applies to the numbers and country origins of refugees among the broader immigrant group. Once in the U.S., refugees have the right to relocate wherever they will, although most, due to service provisions, remain in the short term where they have been placed.

Recruitment of immigrants with special skills that meet the state's or nation's economic development needs represents a very small portion of new immigrants. Along with the temporary non-immigrant visa (H1-B), it is left in the hands of private companies, lawyers, and universities and not controlled by the states. A number of private firms specializing in immigrant visas and placement have sprung up over the years. They are required to register with the state of Georgia. By way of contrast, in 2009, "Canada admitted more employment-based immigrants than the United States" (Gafner and Yale-Loehr, 2010). The Bush administration supported the Comprehensive Immigration Reform Act of 2007, which included a point system that would have increased the emphasis on bringing in highly-skilled workers. In the charged 
political climate regarding "illegal" immigration and with the elections coming, it failed to pass either house.

Even when dealing with legal immigrants, the state of Georgia provides limited services and those only to that small percentage of immigrants classified as refugees. These refugee services are financed by the federal government, which reimburses the state. Georgia, through its Division of Family and Children Services and with support from the federally funded Refugee Resettlement Program and a number of private voluntary agencies, provides refugees with necessary services such as public health (through local county health services), job searches, English-language instruction (under contract with two public junior colleges), and a variety of other services designed to make them self-sufficient and productive (Georgia Government, 2012).

All other legal immigrants (over 85 percent of the total in Georgia) must rely on non-profits and local community organizations for help or pay one of the registered private immigration companies or universities offering fee-driven intensive English programs. We have to remember that, unlike Quebec and Canada, the state's human resource needs in terms of immigration are almost totally outside its control.

For the undocumented the situation is even less welcoming. As the presence of Latinos grew in North Georgia and the metro Atlanta area, state, county, and local governments enacted laws, rules, and regulations that limit access to public services, deny driver's licenses, and restrict public space used for day laborers, as well as collaborated with ICE to identify and deport the undocumented (Lacy and Odem, 2009). The Georgia Code (OGCA, 2011) requires "verification of Lawful Presence within the U.S." as a condition for receiving most "public benefits" except for certain health and educational services mandated by the federal government. Both Georgia House and Senate bills designed to deny undocumented immigrants access to the Georgia University System failed to pass. However, the Board of Regents has, in effect, severely constricted their admission and dramatically increased their costs. For example, undocumented students, even if they graduated from a Georgia public school, must pay out-of-state tuition, which is almost three times that of in-state tuition: US\$28 052 per academic year compared to US\$9 842 to attend the University of Georgia (UGA Admissions, 2012).

On the positive side, school systems have been very active in adapting their programs to the needs of the immigrant community. Churches, particularly the Catholic Church, play a significant role in providing social services and support, which is legally denied to the undocumented by public institutions. Some elements of the private sector are also quite supportive, but behind the scenes. Politicians in Georgia are hard pressed to resist the intense pressure put on them by extreme right-wing anti-immigrant groups. However, they are also cognizant of the needs of the business and agri- 
cultural communities and the role of immigrants in the economic development of the region and state (Odem and Lacy, 2009). Publicly pushing for rigorous laws while privately expecting lax or selective enforcement has become the norm for some moderate politicians, a stance some have labeled "a wink and a nod" (Maffitt, 2012).

The private sector, particularly the carpet industry, poultry producers, and farmers, have been very proactive in recruiting and attracting workers, largely from Mexico and Central America, to fill their respective industries' labor needs. Historically, whites fleeing Appalachia for better jobs had fulfilled these needs. Growth in demand and the generational decline among whites in following their parents into the factories necessitated a search for a new source of reliable labor (Odem, 2009; Zúñiga and Hernández-León, 2009). In terms of the carpet industry (Hernández-León and Zúñiga, 2003; Zúñiga and Hernández-León, 2009; Russakoff, 2006), it is clear that the recruitment of Mexican workers extended to other areas of heavy Mexican settlement in the U.S., particularly Los Angeles, as well as into Mexico, where billboards touted the opportunities available in Georgia. A friendly environment promoted by the carpet companies, along with growing social capital developed in the area by the Mexican community stimulated relatively large-scale settlement in the previously all-white rural towns of Northwest Georgia.

The companies worked hard to support teachers and necessary changes in the schools; the bi-national, bi-lingual Georgia Project (Hernandez and Zuniga, 2003) is the most dramatic example. They also tried to limit extremist reactions in the press and community. Many local business owners successfully adapted to the growing Latino market. In southern Georgia, the agricultural sector (Vidalia onion farmers in particular), through its congressional delegation, put pressure on the federal government to ease up on the round-ups and deportations of Hispanic laborers needed for the harvest. The availability of reasonably well-paying jobs in Georgia, low housing costs, the ready availability of "documents," and the employers' willingness to accept them produced a growing flow of undocumented workers to the state. Although local politicians, including Georgia's current governor -at the time a congressman-, exploited the angst of longtime white residents, little of substance was done to affect the situation while most of the growth of the immigrant population took place. Hence, labor recruitment took a very different turn in Georgia than was the case in Quebec. 


\begin{tabular}{|c|c|c|}
\hline \multicolumn{3}{|c|}{$\begin{array}{c}\text { Table } 5 \\
\text { COMPARISON OF QUEBEC'S AND GEORGIA'S IMMIGRANT POLICIES }\end{array}$} \\
\hline & Quebec & Georgia \\
\hline Constitutional responsibility & Joint, province and federal & Federal-minor role for the state \\
\hline $\begin{array}{l}\text { Number of legal } \\
\text { immigrants annually }\end{array}$ & 52000 provincial primarily & $\begin{array}{l}28 \text { 000, totally federal, except } \\
\text { refugees }\end{array}$ \\
\hline Undocumented immigrants & 25 000, approximately & 450 000, approximately \\
\hline Legal enforcement & $\begin{array}{l}\text { Federal-Canada Border } \\
\text { Services Agency (CBSA) }\end{array}$ & $\begin{array}{l}\text { Federal (ICE) plus state and local } \\
\text { police in some localities; section of } \\
\text { the Immigration and Nationality Act; } \\
\text { and Secure Communities Program }\end{array}$ \\
\hline Recruitment effort & $\begin{array}{l}3 \text { overseas offices, } 7 \text { regional } \\
\text { offices in Quebec }\end{array}$ & $\begin{array}{l}\text { None formally; economic develop- } \\
\text { ment; some refugee group selec- } \\
\text { tion; international students }\end{array}$ \\
\hline Recruitment criteria & $\begin{array}{l}\text { Point system-Quebec } \\
\text { certification-language, } \\
\text { economic, age }\end{array}$ & $\begin{array}{l}\text { Federal govt. family reunification; } \\
\text { regional representation, lottery }\end{array}$ \\
\hline Economic immigration & Dominant form (69\%) & Relatively minor (13\%) \\
\hline Family reunification & $\begin{array}{l}\text { Important but secondary } \\
(20 \%)\end{array}$ & Dominant form (65\%) \\
\hline Refugees & Modest (10\%) & Modest, but state involved (16\%) \\
\hline Main source countries & $\begin{array}{l}\text { Morocco, Algeria, China, } \\
\text { France, Haiti }\end{array}$ & $\begin{array}{l}\text { India, China, South Korea, Viet- } \\
\text { nam }\end{array}$ \\
\hline $\begin{array}{l}\text { Support for immigrants' } \\
\text { language }\end{array}$ & $\begin{array}{l}\text { Quebec sponsors for all } \\
\text { immigrants, French language }\end{array}$ & $\begin{array}{l}\text { State covers English for refugees } \\
\text { only; PVO/NGo, church support }\end{array}$ \\
\hline $\begin{array}{l}\text { Support for immigrants' } \\
\text { health }\end{array}$ & Quebec government & $\begin{array}{l}\text { Refugees only-federal support, } \\
\text { PVo/NGO, church support }\end{array}$ \\
\hline $\begin{array}{l}\text { Support for immigrants' } \\
\text { family services }\end{array}$ & $\begin{array}{l}\text { All immigrants- Quebec } \\
\text { government + Ncos }\end{array}$ & $\begin{array}{l}\text { Refugees only-federal support, } \\
\text { PVO/NGO, church support }\end{array}$ \\
\hline $\begin{array}{l}\text { Support for immigrants' } \\
\text { integration }\end{array}$ & $\begin{array}{l}\text { All immigrants- Quebec } \\
\text { government + NGos }\end{array}$ & Federal and Ncos, church \\
\hline Integration of values & $\begin{array}{l}\text { All immigrants- Quebec govt } \\
\text { + Ncos, includes Quebec } \\
\text { Values document }\end{array}$ & $\begin{array}{l}\text { Federal and NGOS, U.S. American } \\
\text { history and government exam }\end{array}$ \\
\hline $\begin{array}{l}\text { Subnational government } \\
\text { organization }\end{array}$ & $\begin{array}{l}\text { Ministry of Immigration } \\
\text { and Cultural Communities } \\
(>1600 \text { staff) }\end{array}$ & $\begin{array}{l}\text { Department of Family Services, } \\
\text { Secretary of State }\end{array}$ \\
\hline $\begin{array}{l}\text { Temporary work and } \\
\text { education visas }\end{array}$ & Quebec & Federal \\
\hline 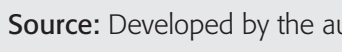 & 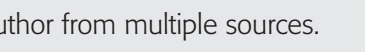 & \\
\hline
\end{tabular}




\section{The Key Dependent Variable: Naturalization and Retention of Immigrants}

Key measures of the success of immigration programs include the level and rate of naturalization (citizenship). Of the MIPEX measures related to naturalization, "access to nationality," Canada and the U.S. both rank quite high. Canada is third among the 31 MIPEX countries, with a score of 74, behind only Portugal and Sweden, which score 82 and 79 respectively. The U.S. comes in at seventh for the access-to-nationality measure, with a score of 61 . When we look at the relationship between the overall score of each of the 31 countries in the MIPEX data base and the access-to-nationality measure, the correlation is extremely high, $(\mathrm{r}=.86, \mathrm{n}=31)$, showing that this measure alone accounts for much of the variation in the MIPEX score $\left(\mathrm{R}^{2}=.73\right)$. Thus, it can be argued that it is relatively more important than any of the other measures included.

Naturalization rates among documented immigrants in Georgia are consistent with levels throughout the U.S., but far below those in Quebec and Canada. In 2012, over 17000 immigrants became naturalized citizens in Georgia. Remember, legal immigrants to Georgia are predominately Asian, a group that generally has a high naturalization rate. Latinos, on the other hand, especially Mexicans, have low naturalization rates, but there are relatively few "documented" Mexican immigrants in Georgia -or most other southern states for that matter. Retention rates (those remaining in the state after naturalization) of legal immigrants to Georgia are hard to pin down, but the level appears to be quite high, especially in the Atlanta metropolitan area, where most new immigrants to the state settle.

Canada has one of the highest and most rapid rates of naturalization of any country in the world. Integration programs are supposed to teach new immigrants about Canada, its history, values, and culture. In fact, this is emphasized in all provinces except Quebec. In Quebec, the history, culture, and values of Quebec are taught but little attention is paid to Canada. It is interesting to note that despite this, a recent survey in Quebec found that over nine in ten recent immigrants (92 percent of Francophones and 91 percent of non-Francophones) "say they are attached to Canada" (Leger Marketing, 2013). This compares to 95 percent for Ontario. The conclusion drawn by the authors of that study is that immigrants to Quebec, regardless of linguistic preference, overwhelmingly identify with Canada, rather than Quebec. Furthermore, naturalization rates in Quebec (73 percent) are not significantly different from those in Ontario (77 percent, the highest provincial rate) or in Canada as a whole (76 percent) (CIC, 2013). This is, at least in part, associated with the fact that administratively, access to citizenship in Canada is among the least burdensome among advanced industrial countries (MIPEX, 2010; OECD, 2011). As a result, of those who have immigrated 
to Canada, the naturalization rate after 6 to 10 years is 71 percent, while the comparable rate in the U.S. is only 24 percent. After 20 years residence, the rates increase to 89 percent for Canada and 74 percent for the U.S. This is consistent with the argument that ease of naturalization is a critical factor.

In addition, however, we need to look at the immigrant support services provided as a contributing factor to integration. Canada's significant investment in integration programs clearly contributes to its success. On the intercultural education measure Canada scores a 71, ranking it third, while the U.S., with a score of 44 , is in the bottom half of the MIPEX countries on this measure. In the U.S., the general lack of integration services significantly slows down the rate of naturalization and delays it until later in life for many immigrants.

The retention rates of immigrants who settle in Quebec are difficult but not impossible to measure, as there is a lag of a minimum of three years between becoming a permanent resident and the opportunity for naturalization. The typical period for naturalization in Canada from time of arrival is six to seven years. Furthermore, since all immigrants have full rights under the Canadian Charter, they are free to move about the country as they choose.

A recent study of retention rates comparing tax data between 2006 and 2010 was designed to see if immigrants had remained or moved to a province other than the one where they originally settled. The highest retention rates are in the largest immigrant-receiving provinces: Ontario, Alberta, British Colombia, and Quebec. The retention rate for all of these is about 90 percent (Immigration Canada, personal communication). This would indicate that the settlement and integration services in these provinces are strong, roughly equivalent, and very successful. These programs build on social capital with fellow immigrants and relatives. What is clear, however, is that even though Quebec manages its own integration services with federal transfer payments, it is neither more nor less successful than other provinces that rely on federal integration programs more directly, but far more successful than Georgia and other U.S. states.

\section{Conclusions}

Immigration policy has become a very salient issue for both states and provinces in the United States and Canada. I employ two different approaches to analysis of this issue. First, I examine the cross-national, quantitative MIPEX index to identify the broad range of issues and measures that impact and define the immigration factors nationally. Then, I employ case studies of the province of Quebec and the state of 
Georgia to capture some of the broad range of variation in immigration policy at the subnational (or meso-) level.

At one end of the spectrum, Quebec is able to play an important role at virtually every step of the Canadian immigration policy process. Canada's federal government checks and certifies all immigrants in terms of national security clearances, but by intergovernmental agreement, leaves almost everything else to Quebec. Planning and prioritizing in terms of economic development needs, recruitment, selection, integration services (including language, "Francization") and targeting of needed skill sets are all done provincially (less so by provinces other than Quebec). A point system emphasizing economic needs, education, language ability, and relative youth of potential immigrants is in place. Economic immigration is the dominant, but not the only, type.

Public opinion on legal immigration, despite some reservations associated with "reasonable accommodation" and secular values, has been and remains very favorable to immigration. In fact, Canada is an outlier among industrial countries in terms of opinion on immigration. Quebec fits into that broadly positive, generally favorable range of opinion toward immigrants and immigration.

On the other end of the spectrum is the state of Georgia (and other U.S. states). Georgia's role and influence over legal immigration policy, particularly on the input side, is minimal. The state has no say in the selection, number, qualifications, or integration of immigrants except for the small category of refugees. For refugees and asylum seekers, Georgia, like other states, is consulted before refugees are settled, and it participates, with federal support, in providing a variety of integration services.

However, the policy disconnect is that the vast majority of Georgia's recent immigrants are undocumented. This has become a very salient issue, resulting in the state and various localities becoming involved in efforts to detain and deport "illegals." This is despite the clear economic interests of several of Georgia's important industries that rely heavily on these workers. Due to the virulence of some segments of the anti-immigrant population, most state services, including higher education, are being denied to the undocumented. Even for "legal" immigrants, state involvement in service provision is minimal and does not present a friendly face.

The comparative study of immigration is a relatively new area and most of the research has concentrated on the nation-state as the unit of analysis. The MIPEX index was designed and is being employed for just that purpose at the national level. There is nothing comparable at the increasingly important "meso-" (intermediate) level. The MIPEX data fail to take into account the tremendous variations within countries. Furthermore, the index does not effectively differentiate between independent and dependent variables. In this paper, I chose to measure the success of immigration policy (my dependent variable) in terms of the rate of naturalization and retention of 
immigrants. Doing so provides us with empirical evidence of the contribution of government integration efforts in naturalization outcomes and is mirrored by the very different rates of naturalization in Georgia and Quebec. If we are to undertake a serious comparative effort to assess the relative success of immigration programs, we need to be able to evaluate immigrant integration where it occurs, at the subnational level. That is a process this article aims to contribute to.

\section{BIBLIOGRAPHY}

$A B A$ Now

2012 American Bar Association Commission on Immigration, November.

AMERICAN IMMIGRATION COUNCIL

n.d. "State Immigration Legislation," Immigration Policy Center, www.immigra tionpolicy.org.

\section{Angus ReID GLobal}

2012 "Canadians Are Divided on the Actual Effect of Immigration," January 31. www.angusreidglobal.com/ polls / 44322 / canadians-are-divided-on-the-ac tual-effect -of-immigration.

2010 www.angusreidglobal.com/issue/immigration.

BeAudin, Monique

2012 "What Quebec's Parties Are Offering in the Election," Montreal Gazette, September 2 .

BEeKs, JAMES, and TONy Frye

2012 "A Case Study of Arizona's Petition to the U.S. Supreme Court and the Unintended Impact of Immigration Laws Passed by Georgia," paper presented at the 4th Annual Southeastern Immigration Conference, Kennesaw, Georgia, October 16-18.

BLOEMRAAD, IRENE

2012 "Understanding Canadian Exceptionalism," in Immigration and Pluralism Policy, Migration Policy Institute, http: / / www.migrationpolicy.org. 


\section{THE CANADIAN PRESS}

2013 “Quebec Plans to Take in Fewer Immigrants," October 31.

CARL Vinson InSTITUTE OF GOVERnMENT

2006 Peach State Poll.

Cic (Citizenship And Immigration CANADA)

2013 http:/ / www.cic.gc.ca/ENGLISH/INDEX.ASP.

CIC NEWS

2012 "Federal, Provincial Governments Reach Agreement on Future Canadian Immigration System," http: / /www.cicsnews.com, accessed December 19, 2012.

Citrin, Johnston, and JoHn Sides

2008 "Immigration and the Imagined Community in Europe and the United States," Political Studies, vol. 5, no. 1, pp. 33-56.

Citrin, Johnston, and MatThew Wright

2012 "Do Patriotism and Multiculturalism Collide? Competing Perspectives from the U.S. and Canada," Canadian Journal of Political Science, vol. 45, no. 3, pp. 531-552.

DAVIDOV, ELDAD, and BART MEULEMAN

2012 "Explaining Attitudes towards Immigration Policies in European Countries: The Role of Human Values," Journal of Ethnic and Migration Studies, vol. 38, no. 5, pp. 757-775.

DUPRAS, DANIEL

1993 "NAFTA: Implementation and the Participation of the Provinces," Ottawa, Parliamentary Research Branch, background paper. Provided by the office of the NAFTA Secretariat in Ontario.

fair (Federation For American ImMigration ReForm)

2010 “Georgia Poll Data," http:/ / www.fairus.org/facts / states/poll_GA, www .fairus .org, 2010 state polls. 
FLORIDA, RICHARD

2005 The Rise of the Creative Class, New York, Basic Books.

Fortin, JessicA, and Peter Loewen

2004 "Prejudice and Asymmetrical Opinion Structures: Public Opinion toward Immigration in Canada," paper presented at the Canadian Political Science Association meeting, Winnipeg, June, 3-5.

GAFNER, CHRis, and StePHEN YALE-LOEHR

2010 "Attracting the Best and the Brightest: A Critique of the Current U.S. Immigration System," Fordham Urban Law Journal, vol. 38, pp. 183-215.

\section{Georgia Code}

2011 OGCA 50-36-1, Title 50, Chapter 36, www.lexisnexis.com.

\section{Georgia Government}

201 Refugee Resettlement, Georgia Department of Family and Children Services, www.dfcs.dhs.georgia.gov/ refugee-resettlement.

Gerin-Lajoie, Paul

1989 Combats d'un révolutionnaire tranquille, Montréal, Centre Éducatif et Culturel.

Gogia, Nupur, and Bonnie Slade

2011 About Canada Immigration, Halifax, Fenwood Publishing,

Government of CANAdA, IMmigration And Citizenship

2011a http:/ / www.cic.gc.ca/english/department/laws-policy/agreements/que $\mathrm{bec} / \mathrm{can}$-que -guide.asp.

2011 b http://www.misc.gouv.qc.ca.

HeRnÁNDEZ-LeÓn, RuBÉN, and Víctor ZúÑIgA

2003 "Mexican Immigrant Communities in the South and Social Capital: The Case of Dalton, Georgia," Southern Rural Sociology, vol. 19, no. 1.

HIEBERT, DANIEL

2006 "Winning, Losing and Still Playing the Game: The Political Economy of Immigration in Canada," Tijdschrift voor Economische en Sociale Geografie, vol. 97, no. 1 (February), pp. 38-48. 


\section{HOCKING, BRIAN}

1999 "Patrolling the 'Frontier': Globalization, Localization, and the 'Actorness' of Non-central Governments," in Francisco Aldecoa and Michael Keating, eds., Paradiplomacy in Action. Foreign Relations of Subnational Governments, London, Frank Cass Publishers.

HOCKING, BRIAN, ed.

1993 Foreign Relations and Federal States, London, Leicester University Press.

Hoefer, Michael, Nancy Rytina, and Brian BaKer

2012 "Estimates of Unauthorized Immigrant Population Residing in the United States: January 2011," Office of Immigration Statistics, Department of Homeland Security, March.

\section{HuFFINGTON POST}

2012 August 20.

JEDWAB, JACK

2008 "Uses and Abuses of Public Opinion Surveying on Issues of Identity," Metropolis, Power Point presentation, www.lexisnexis.com, November 20.

Lacy, Elaine, and Mary Odem

2009 "Popular Attitudes and Public Policies: Southern Responses to Latino Immigration," in Mary Odem and Elaine Lacy, eds., Latino Immigrants and the Transformation of the U.S. South, Athens, Georgia, University of Georgia Press.

LIJPHART, AREND

1971 "Comparative Politics and the Comparative Method," American Political Science Review, vol. 65, no. 3 (September), pp. 682-693.

MAFFiTT, KENNETH

2012 "From 'the Big Wink' to the Big Rebuff: The Rise of Georgia's Immigration Enforcement Complex," paper under review for publication, Migration Integration Policy Index (MIPEX).

MCILORY, JAMES P.

1997 "NAFTA and the Canadian Provinces: Two Ships Passing in the Night," Canada-United States Law Journal, vol. 23, pp. 431-440. 
MIPEX (Migration Integration Policy Index)

2012 www.mipex.eu.

2010 www.mipex.eu.

National Post

2011 December 12.

Nossal, KIm R.

1997 The Politics of Canadian Foreign Policy, 3rd edition, Scarborough, Ontario, Prentice-Hall Canada.

ODEM, MARY

2009 "Latino Immigrants and the Politics of Space in Atlanta," in Mary Odem and Elaine Lacy, eds., Latino Immigrants and the Transformation of the U.S. South, Athens, Georgia, University of Georgia Press, pp.112-125

Odem, Mary, and Elaine LACY

2009 Latino Immigrants and the Transformation of the U.S. South, Athens, Georgia, University of Georgia Press.

Pew Research, Center for the People and the Press

2013 "Public Sees U.S. Power Declining as Support for Global Engagement Slips," America's Place in the World 2013, December 3, http: / / www.people-press.org / 2013/12/03 / section-2-views-of-trade-and-the-global-economy/.

n.d. www.people-press.org.

REITZ, JEFFREY

2011 Pro-immigration Canada, IRPP Study, www.irpp.org.

RUSSAKOFF, DALE

2006 “U.S. Border Town, 1,200 Miles from the Border. Georgia's 'Carpet Capital' Relies on Immigrants," Washington Post, July 17.

SÉGuin, RheAl, and CAMpBell CLARK

2012 "Reasonable Accommodation, Religion Come to the Fore in Quebec Election," Globe and Mail, August 15. 
SimOn, RitA, and Keri SiKICH

2007 "Public Attitudes toward Immigrants and Immigration Policy across Seven Nations," International Immigration Review, vol. 41, pp. 956-962.

SURVEYUSA RESEARCH INNOVATION

2005 www.surveyusa.com/50State2005/50Stateimmigration05128ByState.htm.

UGA (University of GeORgIA) Admissions

2012 www.admissions.uga.edu.

WEISS, DEBRA

2012 "Supreme Court Overturns Three Sections of Arizona Immigration Law, Upholds Paper Checks," ABA Journal, June 25.

WhITE, KENNETH

2012 "Dual Federalism and Immigration in the United States," paper presented at the 4th Annual Southeastern Immigration Conference, Kennesaw, Georgia, October 16-18.

Winter, E., and M. SAuvageau

2012 "La citoyenneté canadienne dans la presse écrite anglo-canadienne et francoquébécoise: convergence ou divergence?" Canadian Journal of Political Sciencel Revue canadienne de science politique, vol. 45, no. 3, pp. 553-578.

ZÚÑIgA,Víctor, and RubÉN HERNÁNDEZ-LEÓN

2009 "The Dalton Story," in Mary Odem and Elaine Lacy, eds., Latino Immigrants and the Transformation of the U.S. South, Athens, Georgia, University of Georgia Press, pp. 34-50. 